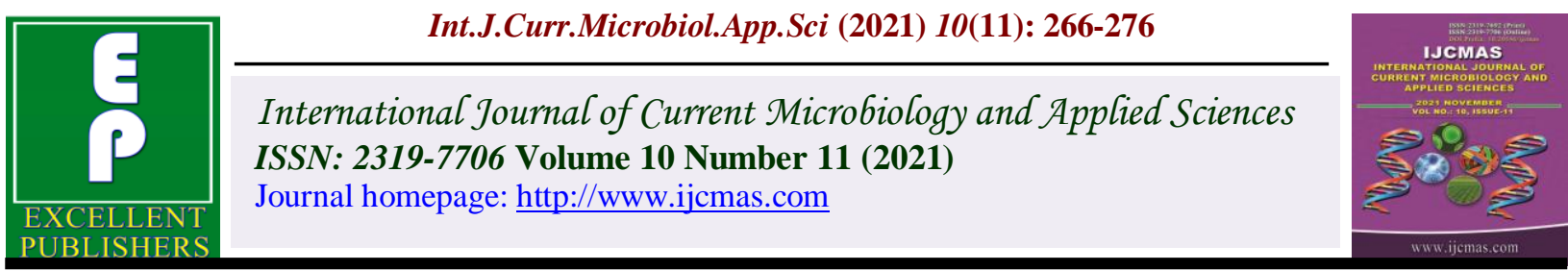

Review Article

https://doi.org/10.20546/ijcmas.2021.1011.031

\title{
Incidence and Management of Bamboo Diseases in North East India
}

\author{
Gurpreet Kaur Bhamra $^{1 *}$ and Rajib Kumar Borah ${ }^{2}$ \\ ${ }^{1}$ Department of Plant Pathology, Assam Agricultural University, Jorhat, India \\ ${ }^{2}$ Rain Forest Research Institute, Jorhat, India \\ *Corresponding author
}

\section{Keywords}

Bamboo diseases, Web blight, Culm rot, Bamboo blight, Northeast India

\section{Article Info}

Received:

15 October 2021

Accepted:

06 November 2021

Available Online:

10 November 2021
Bamboo is an indispensable plant resource for the rural people of Northeast India due to its diverse use in everyday life. In India, there are about 136 species of bamboo belonging to 23 genera, covering an area of about 14 million hectares. Of these, the Northeastern region has 15 genera and 90 species covering 29,396 sq. km, which comprises of about $28 \%$ of the total bamboo growing area in the country. However, the production potential of bamboo is greatly affected by various biotic and abiotic factors viz., erratic rainfall, fire, grazing, unscientific harvesting and pests and diseases. A total 437 microbes, belonging to 12 phyla and 46 orders have been reported to affect bamboos in India. However, only 37 fungal diseases have been reported to affect bamboos in Northeast India of which, 6 are nursery diseases and 31 are plantation diseases. Among these, web blight disease of bamboo caused by Rhizoctonia solani in Bambusa bambos is one of the most serious emerging diseases of bamboo nurseries. The fungus grows in a very rapid manner which can eventually destroy the whole nursery bed within a few days of infection. Foliar spray of Validamycin $(0.1 \%)$ or Propiconazole $(0.1 \%)$ at an interval of 15 days after emergence of seedlings proved to be an effective control measure for the disease. Among the diseases in plantations, culm rot and bamboo blight disease caused by Fusarium udum, is the most severe disease affecting economically important bamboo plantations viz., Bambusa balcooa, B. tulda and B. nutans in Assam. The disease is most common in the flood affected areas and could be managed by adopting routine cultural practices followed by soil drenching with Carbendazim @ $0.1 \%$ twice (once before and once after the emergence of new shoots).

\section{Introduction}

Bamboo is a group of tall arborescent grasses, belonging to the subfamily Bambusoideae and the family Poaceae found in forest areas and widely spread in farmlands, riverbanks and rural areas. Bamboos are fast growing versatile plant species with multiple end uses. For centuries, bamboos have been closely related to the agriculture, cottage industry, arts, culture and day to day life of more than half of the world population. With the 
alarming shrinkage of forest resources and the restriction improved on logging from natural stands, emphasis is being placed on raising fast growing, multipurpose tree species to meet the ever increasing demand for wood. It has now gained International recognition as an important non timber woody resource in the afforestation and reforestation programmes of many Asian countries, bamboos has assumed considerable importance to meet industrial and rural requirements, and also as a means of checking soil erosion and conserving soil. Their versatility, rapid growth and many enduses have made bamboo the backbone of rural economy in many Asian countries. India has the largest diversity of bamboo in the world next to China, with a total of 136 species of bamboo belonging to 23 genera, covering an area of about 14 million hectares. Of these, the North-eastern region has 15 genera and 90 species covering 29,396 sq. $\mathrm{km}$, which comprises of about $28 \%$ of the total bamboo growing area in the country. In the northeast, Bambusa, Dendrocalamus, Dinochloa, Cephalostachym and Neohouzeana etc. are found to be distributed in the region upto 600 $\mathrm{m}$ above mean sea level. On the other hand, species of the bamboo genera such as Arundinaria, Semiarundinaria, Chimonobambusa, Thamnocalamus and Phyllostachys etc. are found up to an elevation of 800-3500 m above mean sea level (Hazarika, et al., 2008). From an economical point of view, it helps a nation grow by providing a source of income for many people. Bamboos are used as industrial raw material for pulp and paper, construction and engineering materials, health food, handicrafts, etc. There is an ever increasing demand of bamboo and bamboo products in the world resulting in enormous economic potential to generate employment opportunities for the people. Despite of the vast diversity of bamboo, diseases contribute an important role in limiting its production potential. Very little has been studied about the bamboo diseases in northeast India. This paper reviews the incidence of bamboo diseases and management of some important and destructive diseases of bamboos prevailing in the north-eastern region of India.

\section{Bamboo Diseases of Northeast India}

The warm and wet climatic conditions prevalent in the northeast India are very conducive for development of diseases. Bamboo are mostly found in forest areas and home gardens, where the economic losses due to diseases is very less. This might be a reason why not much work has been done in this regard. Despite of this, a few diseases have been reported which are mention in the Table 1(nursery diseases) and Table 2(plantation diseases). Out of all these diseases, web blight is a major disease of bamboo nurseries and culm rot and bamboo blight of the bamboo plantations.

\section{Web Blight-A Major Disease in Bamboo Nursery}

Web blight disease caused by Rhizoctonia solani fungi, is one of the most dreaded disease of bamboo under nursery condition. It was first reported in India from Kerela in four different species of bamboo viz., Bambusa bambos, Dendrocalamus strictus, Dendrocalamus brandisii and Thyrsostachys siamensis (Mohanan, 1994) and from Assam in Bambusa bambos (Borah, 2019). The pathogen is also known to cause diseases in other important forest trees viz., Khasi pines, Casuarina equisetifolia, Ailanthus triphysa, Azadirachta indica, Bombaxceiba, Cassia nodosa, Ceibapentandra, Derris robusta, Eucalyptus spp., Gmelina arborea, Michelia champaka (Mehrortra, 1989, Mohanan and Sharma, 1993, Sarma and Sankaran, 1984; Florence et al., 1985; Ali, 1993). Rhizoctonia solani Kühn. is the asexual, imperfect or anamorphic stage and Thanatephorus 
cucumeris (Frank) Donk. is the sexual, perfect or teleomorphic stage of the pathogen causing web blight of bamboo. It is a cosmopolitians oilborne fungus with a very wide host range attacking a large number of plants and weeds (Ou, 1972). In bamboos, $R$. solani causing web blight belongs to AG1-IA, AG1-IC and AG2-2IV (Mohanan, 1994).

Mohanan, 2017 described the symptoms of web blight as water-soaked lesions on the seedling stem near the soil surface. The infection then spreads rapidly to the entire shoot and also to the neighbouring healthy plants. The lesions become greyish brown to dark brown over the next few days. The disease usually occurs in small patches of 5-10 seedlings in the seedbed. The infected patches merge and form large patches of disease. The affected seedlings have shades of greyish brown, purple, and green. The fungal mycelium also develops on the affected stems and leaves. The fungus mycelium penetrates the leaf and stem tissues and spreads rapidly within the seedlings. The disease spreads by physical contact with the nearby seedlings. The heavy rain and overcast weather during the first couple of days can cause the diseases to spread. Other factors include high density of seedlings, thick shading over seedbeds and free water on seedlings.

Borah et al., 2019 observed similar symptoms on the web blight infected seedlings. Greyish brown to dark brown spots surrounded by a yellow halo were observed on the infected leaves which later on coalesced covering larger areas of foliage. The symptoms initiated as water soaked lesion on the stem near soil level and resulted in complete necrosis and withering of the entire foliage. Climatic conditions and seedling density affected the disease spread. The infected seedlings die within 20-25 days of infection leaving a large circular to irregular patches of dried up seedlings in seedbeds.
Management measures for the control of web blight of bamboo seedlings include sanitation, cultural practices, and use of fungicides. Mohanan, 1994 recommended solarization of seedbeds and treatment of seeds with antagonists like Trichoderma harzianum and $T$. viride to reduce the disease incidence. Borah et al., 2019 worked on the management of web blight using chemicals. Foliar spray of Validamycin @ $0.1 \%$ reduced the disease severity to $16.17 \%$.

\section{Culm Rot \& Bamboo Bight- A Major Disease In Bamboo Plantations}

Among the diseases in plantations, culm rot and bamboo blight disease caused by Fusarium udum, is the most severe disease affecting economically important bamboo plantations viz., $\quad$ Bambusa balcooa, $B$. tuld $a$ and $B$. nutans in Assam. It was first reported by Borah, 2006 from Northeast India.

Culm rot and bamboo blight are the two terms used for expressing the stages of infection based on the age of the culm at which average infection occurs and the type of symptoms it develops. Culm rot is usually seen in the emerging shoot, still covered with the culm sheaths in the height category of less than or equal to $40 \mathrm{~cm}$. Blight symptoms appear when the culm is nearing full growth or shortly after this. There are slight variations in symptoms developed during culm rot and bamboo blight stage of infection in different species of bamboo.

During the culm rot stage, the affected shoot initially show brown discolouration and wet rot, starting from the top resulted in rotting of the entire shoot. Eventually, all such affected shoots die and disintegrate. Shortening of the internodes is seen in Bambusa nutans. Blight symptoms develop after the culm reaches a height of $9-10 \mathrm{~m}$. However, the height may vary with bamboo species infected. The 
symptoms initiate as water soaked circular brown spots on the apical culm sheath. Subsequently, the centre of the spot turns greyish in colour with a dark brown margin. Later on, the spots coalesced to form large infected patches.

The blight symptoms first appeared on the culm sheaths of the apical portion of the culm as water soaked lesions. Subsequently, the centre of the spot turned greyish with a dark brown margin. Later on, the symptoms covered the culm sheath and the sheath gets detached. When the culm sheaths got detached from the culm, the reddish brown discoloration progressing downward from the culm node developed. At the same time, internode portion was also seen affected. In Bambusa balcoa, initially elongated spots develop with greyish white centre and dark brown margin. Later on, the colour changes to reddish brown with depressed centre. The internodes covered by apical culm sheaths does not expand fully in Bambusa tulda. While in, Bambusa nutans, the lesion on the internode develops in $\mathrm{V}$ shape with the periphery of dark brown and brownish colour in the middle. After a few days, the lesion cover the whole internode and became whitish in colour and slowly dried up. Discoloration and dieback starts from the top which later on breaks off and hangs giving it a truncated appearance.

Table.1 Diseases reported from bamboo nurseries in the Northeast India

\begin{tabular}{|c|c|c|c|c|c|}
\hline $\begin{array}{l}\text { Sl. } \\
\text { No. }\end{array}$ & Disease & Causal Organism & $\begin{array}{l}\text { Bamboo species } \\
\text { affected }\end{array}$ & Citation & $\begin{array}{l}\text { Location/ } \\
\text { State }\end{array}$ \\
\hline 1 & Leaf spot & Balladyna butleri & Bambusa sp. & $\begin{array}{c}\text { Sydow et } \\
\text { al., (1911) }\end{array}$ & $\begin{array}{l}\text { Khasi hills, } \\
\text { Meghalaya }\end{array}$ \\
\hline 2 & Leaf blight & Helminthosporium bambusae & $\begin{array}{c}\text { Bambusabambos, } \\
\text { Dendrocalamu } \\
\text { sstrictus, Bambusa } \\
\text { spinosa }\end{array}$ & $\begin{array}{l}\text { Tewari } \\
\text { (1992), } \\
\text { Panda } \\
\text { (2011) }\end{array}$ & Assam \\
\hline 3 & Leaf blight & Leptosphaeria graminium & $\begin{array}{l}\text { Phyllostachys sp., } \\
\text { Dendrocalamus sp. }\end{array}$ & $\begin{array}{l}\text { Panwar et } \\
\text { al., (1973); } \\
\text { Tewari } \\
\text { (1992). }\end{array}$ & $\begin{array}{l}\text { Shillong, } \\
\text { Meghalaya }\end{array}$ \\
\hline 4 & $\begin{array}{c}\text { Phyllachora } \\
\text { leaf blight, } \\
\text { Leaf spot }\end{array}$ & Phyllachora shirariana & $\begin{array}{c}\text { Bambusatulda, } \\
\text { Arundinaria }\end{array}$ & $\begin{array}{l}\text { Borah et } \\
\text { al., (1998a) }\end{array}$ & Assam \\
\hline 5 & Leaf stripes & Plectoridium minor & Bambusabalcooa & $\begin{array}{c}\text { Borah et } \\
\text { al., (1998a) }\end{array}$ & Assam \\
\hline 6 & Web blight & Rhizoctonia solani & Bambusabambos & $\begin{array}{c}\text { Borah } e t \\
\text { al., (2019) }\end{array}$ & $\begin{array}{l}\text { Jorhat, } \\
\text { Assam }\end{array}$ \\
\hline
\end{tabular}


Table.2 Diseases reported from bamboo plantations in the Northeast India

\begin{tabular}{|c|c|c|c|c|c|}
\hline $\begin{array}{l}\text { Sl. } \\
\text { No. }\end{array}$ & Disease & Causal Organism & $\begin{array}{c}\text { Bamboo species } \\
\text { affected }\end{array}$ & Citation & $\begin{array}{l}\text { Location/ } \\
\text { State }\end{array}$ \\
\hline 1 & $\begin{array}{l}\text { Black culms } \\
\text { and dead stem } \\
\text { of bamboo }\end{array}$ & Anthostomella bambusae & Bambusa sp. & $\begin{array}{c}\text { Leveille } \\
\text { (1845), Patil et } \\
\text { al., (1980). }\end{array}$ & $\begin{array}{l}\text { Nangki } \\
\text { Hills, } \\
\text { Assam }\end{array}$ \\
\hline 2 & Culm Spot & Apiospora indica & Bambusa sp. & $\begin{array}{c}\text { Sydow and } \\
\text { Butler (1916) }\end{array}$ & $\begin{array}{l}\text { Nangki } \\
\text { Hills, } \\
\text { Assam }\end{array}$ \\
\hline 3 & $\begin{array}{l}\text { Black leaf } \\
\text { spot and culm } \\
\text { stain }\end{array}$ & Balladyna butleri & Bambusa sp. & $\begin{array}{c}\text { Butler and } \\
\text { Bisby (1931, } \\
\text { 1960) } \\
\text { Mohanan } \\
\text { (2002) }\end{array}$ & $\begin{array}{c}\text { Khasi } \\
\text { hills, } \\
\text { Meghalaya }\end{array}$ \\
\hline 4 & $\begin{array}{l}\text { Bipolaris leaf } \\
\text { blight }\end{array}$ & Bipolaris sp. & $\begin{array}{c}\text { Bambusa tulda, B. pallida } \\
\text { and Dendrocalamus } \\
\text { hamiltonii }\end{array}$ & $\begin{array}{c}\text { Borah and } \\
\text { Sarma (2002) }\end{array}$ & $\begin{array}{l}\text { Jorhat, } \\
\text { Assam }\end{array}$ \\
\hline 5 & $\begin{array}{l}\text { Decay and } \\
\text { deterioration } \\
\text { of culms }\end{array}$ & $\begin{array}{l}\text { Clypeosphaeria } \\
\text { crenulatum }\end{array}$ & Bambusa sp. & $\begin{array}{c}\text { Berkeley } \\
(1856)\end{array}$ & $\begin{array}{l}\text { Nangki } \\
\text { hills, } \\
\text { Assam }\end{array}$ \\
\hline 6 & Leaf spot & Curvularia lunata & Bambusa pallida & $\begin{array}{l}\text { Debnath et al., } \\
\text { (2018) }\end{array}$ & Tripura \\
\hline 7 & Leaf strips & Didymella sp. & Bambusa nutans & $\begin{array}{l}\text { Borah et al., } \\
\text { (1998a) }\end{array}$ & Assam \\
\hline 8 & Leaf spot & Drechslera rostrata & Bambusa pallida & $\begin{array}{l}\text { Debnath et al., } \\
\text { (2018) }\end{array}$ & Tripura \\
\hline 9 & $\begin{array}{l}\text { Brown Leaf } \\
\text { Spot }\end{array}$ & Fusarium pallidoroseum & $\begin{array}{l}\text { Teinostachyum dullooa, } \\
\text { Melocanna humilis }\end{array}$ & $\begin{array}{l}\text { Deka et al., } \\
\text { (1990) }\end{array}$ & $\begin{array}{l}\text { Jorhat, } \\
\text { Assam }\end{array}$ \\
\hline 10 & Leaf spot & Fusarium redolens & Bambusa pallida & $\begin{array}{l}\text { Debnath et al., } \\
\text { (2018) }\end{array}$ & Tripura \\
\hline 11 & $\begin{array}{c}\text { Bamboo } \\
\text { blight }\end{array}$ & Fusarium semitectum & $\begin{array}{l}\text { Bambusa balcooa, } \\
\text { B. tulda }\end{array}$ & $\begin{array}{l}\text { Gogoi et al., } \\
\text { (2013a) } \\
\text { Gogoi et al., } \\
\text { (2013b) }\end{array}$ & Nagaland \\
\hline 12 & $\begin{array}{l}\text { Bamboo } \\
\text { blight and } \\
\text { culm rot }\end{array}$ & Fusarium udum & $\begin{array}{c}\text { Bambusa tulda, B. nutans, } \\
\text { B. balcooa }\end{array}$ & $\begin{array}{l}\text { Borah (2006), } \\
\text { Borah et al., } \\
\text { (2011) }\end{array}$ & Assam \\
\hline 13 & $\begin{array}{c}\text { Branch } \\
\text { necrosis and } \\
\text { tip die-back }\end{array}$ & Fusarium sp. & $\begin{array}{c}\text { Bambusa bambos, } \\
\text { Dendrocalamus strictus }\end{array}$ & $\begin{array}{c}\text { Borah and } \\
\text { Sarma (2002) }\end{array}$ & $\begin{array}{l}\text { Jorhat, } \\
\text { Assam }\end{array}$ \\
\hline 14 & $\begin{array}{l}\text { Grey Leaf } \\
\text { Spot }\end{array}$ & Hendersonula toruloides & Bambusa nutans & $\begin{array}{l}\text { Deka et al., } \\
\text { (1990) }\end{array}$ & $\begin{array}{l}\text { Jorhat, } \\
\text { Assam }\end{array}$ \\
\hline 15 & Decay & Hypoxylon perforatum & Bambusa sp. & $\begin{array}{c}\text { Berkeley } \\
(1856)\end{array}$ & $\begin{array}{l}\text { Nangki } \\
\text { hills }\end{array}$ \\
\hline
\end{tabular}




\begin{tabular}{|c|c|c|c|c|c|}
\hline & & & & & Assam \\
\hline 16 & Leaf spot & Morrisiella indica & Bambusa sp. & $\begin{array}{l}\text { Saikia and } \\
\text { Sarbhoy } \\
\text { (1985); } \\
\text { Mohanan } \\
\text { (2002). }\end{array}$ & Assam \\
\hline 17 & Leaf chlorosis & Paecilomyces lilacinus & $\begin{array}{l}\text { Dendrocalamus } \\
\text { hamiltonii }\end{array}$ & $\begin{array}{l}\text { Deka et al., } \\
\text { (1990); } \\
\text { Mohanan } \\
\text { (2002) }\end{array}$ & $\begin{array}{l}\text { Jorhat, } \\
\text { Assam }\end{array}$ \\
\hline 18 & $\begin{array}{l}\text { Dot like black } \\
\text { pustules }\end{array}$ & $\begin{array}{l}\text { Phaeoisariopsis } \\
\text { bambusae }\end{array}$ & Bambusa nutans & $\begin{array}{l}\text { Borah et al., } \\
\text { (1998a) }\end{array}$ & $\begin{array}{l}\text { North east } \\
\text { India }\end{array}$ \\
\hline 19 & Leaf spot & Phaeoramularia sp. & Bambusa tulda & $\begin{array}{l}\text { Borah et al., } \\
\quad(1998 \mathrm{a})\end{array}$ & $\begin{array}{l}\text { North east } \\
\text { India }\end{array}$ \\
\hline 20 & $\begin{array}{l}\text { Phyllachora } \\
\text { Leaf Spot, } \\
\text { Tar spot }\end{array}$ & Phyllachora ischaemi & $\begin{array}{c}\text { Bambusa balcooa, } \\
\text { B. tulda, } \\
\text { Arundinaria, B. bambos }\end{array}$ & $\begin{array}{l}\text { Borah et al., } \\
\quad(1998 \mathrm{~b})\end{array}$ & Assam \\
\hline 21 & Leaf spot & Phyllachora shiraiana & $\begin{array}{c}\text { Bambusa balcooa, } B . \\
\text { tulda, } \\
\text { Arundinaria }\end{array}$ & $\begin{array}{l}\text { Borah et al., } \\
1998 \mathrm{~b}\end{array}$ & Assam \\
\hline 22 & Leaf stripping & Plectoridium minor & Bambusasp. & $\begin{array}{l}\text { Borah et al., } \\
\text { (1998a) }\end{array}$ & $\begin{array}{l}\text { North east } \\
\text { India }\end{array}$ \\
\hline 23 & $\begin{array}{l}\text { Ochraceous } \\
\text { Pocket Rot }\end{array}$ & Polystictus sanguineus & Bambusa sp. & $\begin{array}{l}\text { Patil et al., } \\
\text { (1980). }\end{array}$ & Assam \\
\hline 24 & $\begin{array}{l}\text { Rhizome \& } \\
\text { Root Rot }\end{array}$ & Poriarhizomorpha & Melocanna baccifera & $\begin{array}{l}\text { Bagchee } \\
\text { (1953); } \\
\text { Spaulding } \\
\text { (1961) }\end{array}$ & Assam \\
\hline 25 & Tar like spot & Pseudocercospora sp. & Bambusa tulda & $\begin{array}{l}\text { Borah et al., } \\
\text { (1998a) }\end{array}$ & $\begin{array}{l}\text { North east } \\
\text { India }\end{array}$ \\
\hline 26 & Tar like spot & Pseudospiropes sp. & Bambusa tulda & $\begin{array}{l}\text { Borah et al., } \\
\text { (1998a) }\end{array}$ & $\begin{array}{l}\text { North east } \\
\text { India }\end{array}$ \\
\hline 27 & Leaf rust & Puccinia melanocephala & $\begin{array}{l}\text { Bambusa sp. } \\
\text { Arundinaria sp. }\end{array}$ & $\begin{array}{l}\text { Sydow et al., } \\
\text { (1907) }\end{array}$ & Assam \\
\hline 28 & Leaf strips & Sirosporium sp. & Bambusa nutans & $\begin{array}{l}\text { Borah et al., } \\
\text { (1998a) }\end{array}$ & Assam \\
\hline 29 & $\begin{array}{c}\text { Brown leaf } \\
\text { spot }\end{array}$ & Sphaerella bambusina & Bambusa sp. & $\begin{array}{l}\text { Sydow et al., } \\
\text { (1911); Patil } \\
\text { et al., (1980). }\end{array}$ & $\begin{array}{l}\text { Wahjain, } \\
\text { Assam }\end{array}$ \\
\hline 30 & Leaf spot & Scaphidium sp. & Bambusa balcooa & $\begin{array}{l}\text { Borah et al., } \\
\quad(1998 \text { a) }\end{array}$ & Assam \\
\hline 31 & $\begin{array}{l}\text { Miscellaneous } \\
\text { Foliage and } \\
\text { Minor Branch } \\
\text { Infections }\end{array}$ & Triglyphium bambusae & Bambusa tulda & $\begin{array}{l}\text { Roy (1966); } \\
\text { Mohanan } \\
\text { (2002). }\end{array}$ & Assam \\
\hline
\end{tabular}


Fig.1 Symptoms of web blight caused by Rhizoctonia solani in bamboo nursery
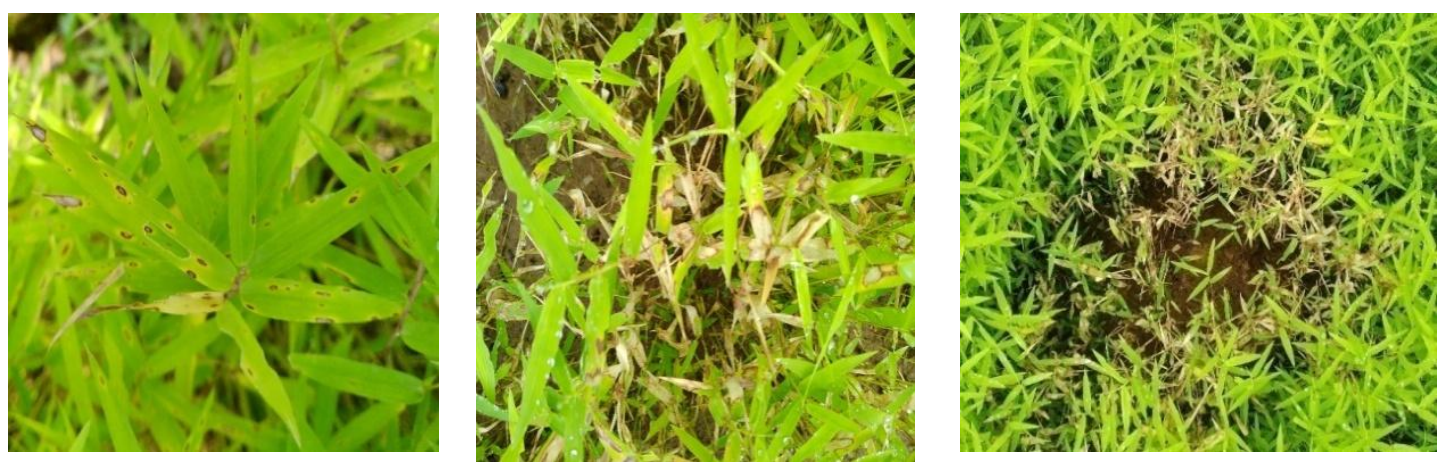

Fig.2 Rotting of the emerging culm

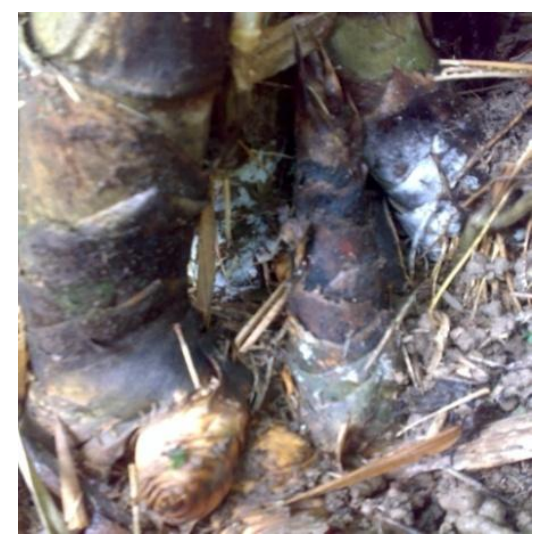

Fig.3(a-b) Bamboo blight symptoms on Bambusa balcooa

a. Reddish brown discoloration

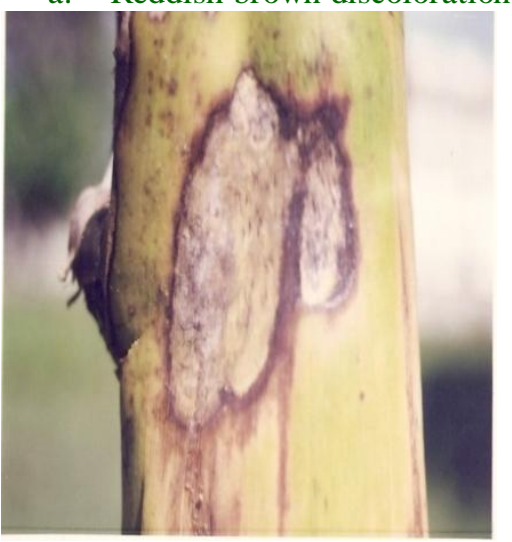

b. Shriveled internode

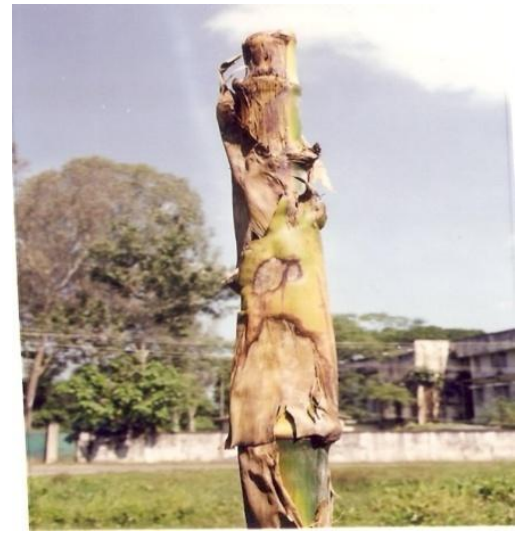


Fig.4(a-b) Bamboo blight symptoms on Bambusa tulda

a. Apical culm curved down

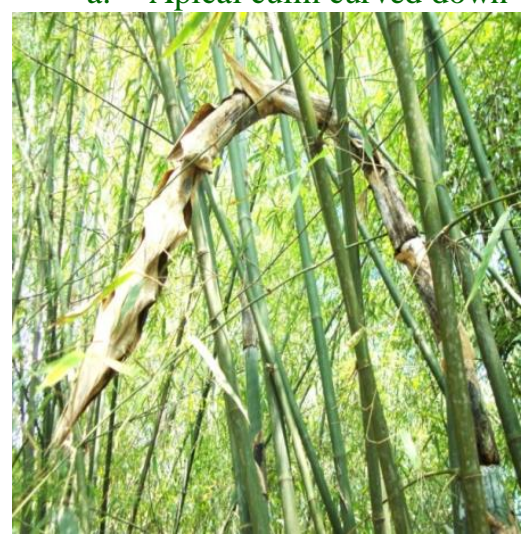

b. Die back portion breaks and hang down

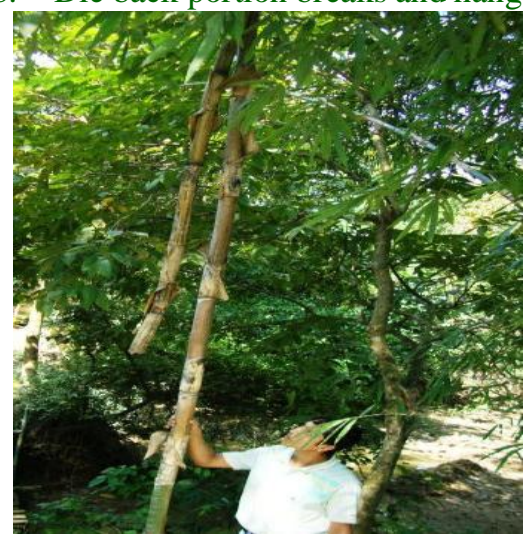

Fig.5(a-b) Bamboo blight symptoms on Bambusa nutans

a. 'V' shaped appearance

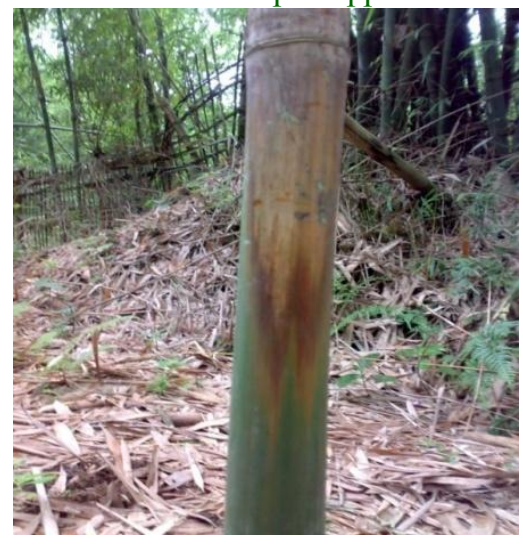

Cultural control measures such as removal of debris around the clumps before the onset of monsoon, light burning of debris over the ground, loosening the soil around the clump before culm emergence, and pruning and removal of branches from the basal part of culm during March-April were recommended for managing rot of emerging culms occurring on Bambua balcooa, B. bambos, B. polymorpha, B. vulgaris, Dendrocalamus longispathus, D. Strictus, Ochladra travancorica, O. scriptoria, Thyrsostachys oliveri stands in Kerela and Karnartaka states of India (Mohanan, 2002). Weeds and bushes around the clumps should be removed as these act as retainers of moisture, which was considered favourable for causing infection. Also recommended application of b. Truncated appearance

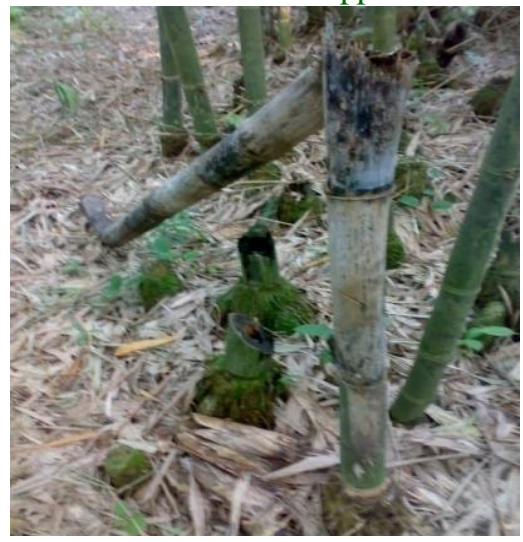

Carbendazin combined with mancozeb (Carbendazim 0.15\% a.i. + Mancozeb 0.3\% a.i.) or with Fytolan (Carbendazim $0.25 \%$ a.i. + Fytolan $0.3 \%$ a.i.). Soil drenching around the bamboo clumps with copper oxychloride and Dithane M-45 was found desirable to check the spread of disease (Rahman, 1988). Combination of Bavistin $(0.16 \%)$ and Dithane M-45(0.3\%) or Fytolan(0.3\%) was effective in managing the bamboo blight in B. nutans (Jamaluddin et al., 1992). Adoption of routine cultural practices followed by soil drenching with Carbendazim @0.1\% twice once before and once after the emergence of new shoots was found to manage the disease and increase the survivality per cent of the culms (Borah, 2006). 
Bamboo being ubiquitous plant of this region, it is woven in the lifestyles of the rural population of North east India and is considered to be as one of the most valuable forest plant, nature has given to mankind. But to exploit its full potential, more research on scientific cultivation and proper management of the plants against the newly emerging insect pests and diseases is thought to be of prime importance.

Various diseases attack the bamboo during different stages and can cause considerable harm to the plant. An essential part of avoiding such losses is proper identification and management of the diseases.

Bamboo forms a major part of the forest of northeast India and it is an integral part of the rural population of region. Till date a total of 37 bamboo diseases have been reported from the forests of Northeast India. Management strategies for the major nursery and plantation diseases have been formulated and reported by various authors, which mainly includes following proper routine cultural practices, application of biocontrol antagonists and chemicals. Web blight disease caused by Rhizoctonia solani is a major nursery disease and can be managed by foliar spray of Validamycin@0.1\%. Culm rot and bamboo blight is another major disease affecting the bamboo stands and can be managed by soil drenching with Carbendazim @ 0.1\% twice once before and once after the emergence of new shoots.

\section{Future Thrust}

Bamboo has an enormous potential in uplifting the rural economy of India especially the North-eastern region. Among the various biotic and abiotic constraints that reduce its growth potential, diseases hold a very critical place. Research should be directed towards proper identification of the diseases and ultimately how to manage them so that bamboo productivity reaches its optimal potential.

\section{References}

Ali, M. I. M. (1993). Studies on seed pathology and seedling diseases of some important indigenous tree species of Kerala, $\mathrm{Ph} \mathrm{D}$ Thesis, Cochin University of Science \& Technology, Kerala, India.

Bagchee, K. D. (1953). New and noteworthy diseases of forest trees and decay in timber in India. Indian Forester 80:373-378

Berkley, M. J. (1856). Decades of fungi, 1620. Journal of Botany3-8: 1844-1856.

Borah, R. K. (2006). Studies on the incidence and management of culm rot and bamboo blight disease. Ph.D. thesis. Assam Agricultural University, Jorhat, Assam.

Borah, R. K. and Sarma, G. S. (2002). A preliminary investigation of bamboo diseases in Assam. Journal of NonTimber Forest Products 9(1/2):5-8

Borah, R. K., Deb, R. R. and Bhamra, G. K. (2019). First report of web blight disease of Bambusa bambos (L.) Voss from Assam and its management using commercially available fungicide. Indian Journal of Tropical Biodiversity 27(2):38-49.

Borah, R. K., Dutta, D. and Hazarika, P. (1998a). Some new records of Fungi from North-east India. Van Vigyan 36 (1): 41-43

Borah, R. K., Dutta, D. And Hazarika, P. (1998b). Three new Phyllachora leaf spots from Assam. Indian Journal of Forestry 21(3):256-258

Borah, R. K., Gogoi, J., Sarmah, G. S., Dutta, B. K. and Gogoi, B. (2011). A preliminary study on the occurrence of blight disease in Bambusa tulda Roxb. 
in Assam. In: Productivity enhancement and value addition of bamboos. Institute of Forest Productivity. pp.80-83

Butler, E. J. and Bisby, G. R. (1931). The Fungi of India. Imperial Council of Agricultural research India Scientific Monograph Imperial, XVIII, 237pp

Butler, E. J. and Bisby, G. R. (1960). The Fungi of India. (Revised by R. S. Vasudeva). Indian Council of Agricultural Research publication, New Delhi India, 522 pp.

Debnath, S., Karmakar, P., Bhattacharjee, S., Majumdar, K., Das, P., and Saha, A. K. (2018). Isolation and identification of fungal assemblages in the necrotic spots of Bambusa pallida (L.) Voss. Annals of Plant Sciences 7.4:21602165.

Deka, P. C., Baruah, G. and Devi, M. (1990). A preliminary investigation of diseases of bamboo in Northeast region of India. Indian Forester 116(9):714-716.

Florence, E. J. M., Sharma, J. K., Sankaran, K. V. And Mohanan, C.(1985). Some diseases of forest tree seedlings in India caused by Sclerotium rolfsii and Rhizoctonia solani. European Journal of Plant Pathology 15: 187-190.

Gogoi, J., Borah, R. K. And Lahan, J. P.(2010). A preliminary investigation of certain bamboo diseases in Dhemaji district of Assam. Journal of Nature and Environment 2.3:50-53.

Gogoi, J., Teron, R. and Tamuli, A. K. (2013a). Incidence of blight and rot diseases of Bambusa tulda Roxb. groves in Dimapur district of Nagaland State. International Journal of Science and Nature 4(3):478-482.

Gogoi, J., Teron, R. and Tamuli, A.K. (2013b). Blight disease of Bambusa balcooa Roxb. : a potential threat to village bamboo groves of Dimapur district in Nagaland state. Dimorian
Review

Hazarika, P., Pandey, B. K. and Khound, A. (2008). A new look on utilization aspect of Bamboo. Chapter 17, Handbook of PCM, Van Vigyan Kendra, Rain Forest Research Institute (ICFRE), Jorhat, Assam.

Jamaluddin, A., Gupta, B. N., Bohidar, S. C and Dadwal, V. S. (1992). Mortality of bamboo (Bambusa nutans Wall.) in coastal areas of Orissa. Journal of Tropical Forestry 8: 252-261.

Leveille, J. H. (1845). Champignons exotiques. Annales des Sciences Naturelles Botanique, Serie 32:167221

Mehrotra, M. D. (1989). Leaf blight of some hardwood species in Meghalaya and its control in the nursery. Indian Forester 6: $378-384$.

Mohanan, C. (1994). Studies on Diseases of Bamboos and Nursery Management of Rhizoctonia Web Blight in Kerala, $\mathrm{Ph}$ D Thesis, Cochin University of Science \& Technology, Division of Forest Pathology, Kerala Forest Research Institute.

Mohanan, C. And Sharma, J. K. (1993). Diseases of Casuarina equisetifolia in India. Common wealth Forestry Review72(1): 48-52.

Mohanan, C. (2002). Diseases of bamboos in Asia- an illustrated manual. International Network for Bamboo and Rattan (INBAR).

Mohanan, C. (2017). Diseases of bamboos in Asia- an illustrated manual. An updated version. International Network for Bamboo and Rattan (INBAR).

Ou, S. H. (1975). Rice diseases. Common Wealth Mycology Institute, Kew, England 2ndEd., pp: 272.

Panda, H. (2011). Bamboo plantation and utilization handbook. Asia Pacific Business Pres Inc. Delhi.

Panwar, K. S., Purohit, D. M. and Gehlot, C. 
(1973). A new species of Xenosporium. Current Science. 42: 734

Patil, N. G., Adiver, S. and Hegde, R. K. (1980). Bamboo diseases. Proceedings of the III Southern Silviculturists and Forest Research Officers Conference, Dharwad, Karnataka, India 3-5 March 1980, 67-69 pp.

Roy, A. K. (1966). A new species of Triglyphium. Sydowia 20: 203-205

Saikia, U. N. And Sarbhoy, A. K. (1985). Morrisiella, a new genus of synnematoushyphomycete. Mycologia 77(2): 318-320

Sarma, J. K. And Sankaran, K. V. (1984). Web blight of Albizia falcataria in
India. European Journal of Plant Pathology14:261-264.

Spaulding, P. (1961). Foreign Diseases of Forest trees of the World. USDA Agriculture Handbook no. 197, United States department of agriculture, Washington D.C., USA

Sydow, H., Sydow, P. and Butler, E. J. (1907). Fungi Indiae Orientalis Pars II. Annals of Mycology 5(6):500.

Syndow, H. and Bulter, E. J. (1911). Fungi Indie Orientalis Pars III. Annual Mycology 10: 243-280

Tewari, D. N. (1992). A monograph on bamboo, International Book Distributors, Dehradun, India. 498 pp

\section{How to cite this article:}

Gurpreet Kaur Bhamra and Rajib Kumar Borah. 2021. Incidence and Management of Bamboo Diseases in North East India. Int.J.Curr.Microbiol.App.Sci. 10(11): 266-276. doi: https://doi.org/10.20546/ijcmas.2021.1011.031 